GEOSPORT FOR SOCIETY
$\begin{aligned} & \text { GeOSPORT } \\ & \text { SOCIETY }\end{aligned}$
Scientific Journal founded in 2014 under aegis of University of Oradea (Romania),
University of Debrecen (Hungary), University of Gdánsk (Poland)
ISSN 2393-1353
Edited by Oradea University Press
1, University Street, 410087, Oradea, Romania
Journal homepage: $h$ ttp://geosport.uoradea.ro/geosport.html

\title{
Daily Physical Education and the Impact of a „Handball at School” Project
}

\author{
István JUHÁSZ ${ }^{1}$, Eszter BODA ${ }^{2}$, Anetta MÜLLER ${ }^{3}$, Melinda BÍRÓ ${ }^{4}$, Anikó MOLNÁR ${ }^{5 *}$, \\ Éva BÁCSNÉ BÁBA ${ }^{6}$, István SOÓs 7, Ian WHYTE ${ }^{8}$
}

1. Eszterházy Károly University, Department of Sport Science and Methodology, Eszterházy square 1., 3300, Eger, Hungary, e-mail: juhaszi@keziszovetseg.hu

2. Eszterházy Károly University, Department of Sport Science and Methodology, Eszterházy square 1., 3300, Eger, Hungary, e-mail: boda.eszter@uni-eszterhazy.hu

3. University of Debrecen, Department of Sports Management, Böszörményi str. 138., 4032, Debrecen, Hungary, email: muller.anetta@econ.unideb.hu

4. University of Debrecen, Sports Science Coordination Institute, Egyetem square 1., 4032, Debrecen, Hungary, e-mail: biro.melinda@sport.unideb.hu

5.* University of Debrecen, Department of Sports Management, Böszörményi str. 138., 4032, Debrecen, Hungary, email: miller.e.annie@gmail.com

6. University of Debrecen, Department of Sports Management, Böszörményi str. 138., 4032, Debrecen, Hungary, email: bacsne.baba.eva@econ.unideb.hu

7. University of Physical Education, Pedagogy and Methodology Department, Alkotmány str. 44., 1123, Budapest, Hungary, e-mail: soos.istvan@tf.hu

8. University of Sunderland, Sport and Exercise Sciences Design Centre, Chester Rd. 138., SR1 3SD, Sunderland, United Kingdom, e-mail: $\underline{\text { ian.whyte@sunderland.ac.uk }}$

* Corresponding author

Citation: Juhász, I., Boda, E., Müller, A., Bíró, M., Molnár, A., Bácsné Bába, E., Soós, I., \& Whyte, I. (2019). Daily Physical Education and the Impact of a „Handball at School” Project. Geosport for Society, 11(2), 59-75. https://doi.org/10.30892/gss.1102-049

Article history: Received: 03.06.2019; Revised: 12.08.2019; Accepted: 20.09.2019, Available online: 23.10.2019

\begin{abstract}
This study identified what effects project Handball at School had on target accuracy amongst primary aged school children ( $n=293$ ) over a 6 month period, who undertook daily PE in school. They were grouped into 3 experimental schools in which intervention took place and 2 control schools. In order to examine target accuracy, technical form, and time in task, 2 tests were applied. The first test involved students in throwing sponge-handballs 5 times with no break at a target from a stationary straddle stand. The aim of the exercise was to hit a small box using an overarm throw. The other test involved running movement. Target accuracy and technical form improved in test 1 across all age groups. In the more dynamic activity with the preceding run technical form improved across all age groups and positive trends were identified in target accuracy, albeit that only one age group recorded significant improvements. The authors suggest that the results indicate the benefits of the Handball at School as a sport specific intervention programme. There is a cautionary note that adding further complexity or speed with children in these groups may contribute some confounding variables.
\end{abstract}


Keywords: handball, daily PE, target accuracy, primary school children

\section{Introduction}

In Hungary significant changes in physical education of the primary and secondary schools were implemented when daily physical education was introduced. The justification for the increase in the number of P.E lessons was the result of concerns about negative health tendencies in Hungary's young people. Recent years have seen a worrying rise of negative health conditions such as asthma, allergies, COPD, high blood pressure, diabetes and coronary diseases, with increases also being evidenced, among young people and children, of the number of physical disabilities such as scoliosis, kyphosis, lordosis, and spondylosis.

The idea of introducing daily physical education in Hungary had been promoted in the country's Sports Strategy (Sport XXI) following research evidence that was presented prior to policy preparation. This research revealed that $75 \%$ of Hungarian children only did regular exercises in physical education lessons, which did not (at that time) ensure the amount of activity necessary for the age group. It was also stated that only $19 \%$ of the students took part in the student Olympics competition system and only 90,000 under- 18 sportspeople ( $6 \%$ of that population) held competition permits indicating participation in sports clubs as part of the federational sports system.

Further support for daily physical education was derived from a Hungarian study in which it was identified that amongst seven-year olds, every fourth girl (25\%) and every fifth boy was classified as being overweight or obese in Hungary in 2010 (Martos et al., 2012). At present there are over twelve million overweight or obese children in the European Union with the number of overweight children growing by 400,000 per year and the number of obese children by 85,000 . This early onset of obesity is a big problem because it is a major risk factor concerning adult- or later obesity (Cole, 2004; Börnhorst et al., 2016). It was anticipated that daily physical education would have an essential role in fighting obesity (Baidog and Herman, 2018; Papp et al., 2019; Tătar et al., 2018). Support for this view was garnered from EU recommendations (Guidelines of EU for Physical Activity, 2008) which stated that school-age children need 60 minutes of moderate intensity exercise per day. Referring to those issues, the Sports Strategy promoted the necessity of introducing daily physical education and noted it as a task to be implemented in the future.

Recently, there have been substantial alterations to curricular content and methods of delivery as a result of Hungarian policy changes outlined in a series of Basic National Curriculum (NAT) documents culminating in the latest edition NAT4 (2012). The latest NAT was approved by the Hungarian government in 2012, based on Government Order 110 (2012) covering objectives such as social-, mental- physical- 
health education. The main goal of the project was to introduce 5 PE lessons per week, as to ensure the daily physical education for every student between the age of 6 and 18 . Beginning in the 2012/2013 academic year, daily physical education became compulsory for three year groups (7, 11 and 15 plus years - classes 1, 5 and 9 respectively). It was then rolled out across the sector until daily physical education for all schoolchildren was fully enacted by the beginning of the 2015/2016 academic year. To meet the objectives and principles of the daily PE, skills must be obtained in both individual sports and team games and alongside knowledge of the history, traditions, and culture of sport and society. Additionally, daily PE is also recognized as a medium that has been used effectively to create pathways for healthy lifestyles and activities. Other purposes of daily physical education relate to the advancement of sports knowledge, developing, and enlarging different kind of movement skills, increasing involvement in leisure sports and creating values based on regular physical activity.

One major plank in supporting the introduction of daily physical education came from another Government initiative known as the TAO system in Hungary (for further information see Bács and Bácsné Bába, 2014). The TAO system was a subsidy system that was developed to support team sports that had both a strong participation outlet as well as a culture and capacity as key spectator (aka visual) sports. Funding was supplied via the Government's Corporate Tax and Dividend Tax. The TAO sport support system for spectator team sports was introduced in our country in 2011 following the modification of Act LXXXI of 1996 on Corporate Tax and Dividend Tax to encompass legal regulation of a 'sports-friendly' tax (András, 2014). This system was supported the following spectator sports: football, basketball, handball, water polo and ice hockey (Bardóczy, 2014).

The resources coming from TAO can be spend by the beneficiaries on tangible investment such as sport infrastructural background, renovation of sport facilities, personal expenses and educational costs. In the 2011 tax year alone the sports purpose contribution of 2618 corporate tax payers were approximately 20.4 bn HUF in tax advantage. By end of year 2012, it had increased to 25 billion HUF (Bardóczy, 2014).

One undisputable merit of TAO is that it plays an exceptional role both in the development of grassroots provision as well as that of professionals' training (Dajnoki et al., 2015). The importance of the 'grassroots' is crucial. The Hungarian data of 2006 cited in the National Sports Strategy (Sport XXI) indicated that there were 200,000 sports people holding competition permits in Hungary. Of this number, 138,000 people were from the 6 popular spectator team sports (handball, football, water polo, basketball, ice hockey and volleyball), albeit that volleyball was only added in 2017. As for handball, the TAO had a positive effect on the increases in participation with year on year growth being shown (2011 there were 24000 persons, in 2012 - 25000 persons, in 2013 - 29788 persons and in 2014- 31227 registered sportsmen (Bardóczy, 2014; András 2014). 
It is not TAO system alone that plays an essential developmental role in our country. A good example is the relatively novel Handball at School project operated by the Hungarian Handball Federation which also could increase the number of school aged children in sports clubs. This was supported by the TAO funds.

The Hungarian Handball Association took advantage of this favourable educational-political environment to get involved in daily PE to promote its sport through its Handball at School project. Its aim was to enrich the curriculum and develop ball skills with age-appropriate practices and material, promoted through the delivery of two handball lesson per week from the five physical education lessons.

\section{Summary of the "Handball at School" Programme}

The Handball at School programme of the Hungarian Handball Association was introduced and implemented in 2013 in 50 primary schools, with 54 participating physical education teachers and 1430 children. Following favourable responses from teachers and children alike, the programme was enlarged in 2014 to cover 91 schools, with 98 physical education teachers actively promoting it amongst 3400 participating children. As of today - as a result of further extension in 2015 - the project is being run in 117 schools by 127 physical education teachers with a concomitant increase in participation to almost 4565 students ( 7 - 14/15-year olds). One thousand four hundred and thirty-five participants were in junior school aged between 8 and 11 years and the programme and the schools taking part in the project have enlarged the base of youth handball participation. A concomitant affect is that the project has also become a dominant nursery for talent identification and development.

The participating children aged 8-11 (albeit this study only tested 8-10-year olds due to sampling issues) years learn basic handball rules and technical and tactical items of handball twice a week. They also undertake numerous kinds of ball-specific drills (to improve dexterity and skills) by using lighter handballs (sponge-handballs) and compete in mock or fun competitions during the lesson. PE teachers, required to take part in the project were trained by the Hungarian Handball Federation and the schools were given the needed handball equipment. The results of the programme are monitored through a mentor system as well as by reviewing lesson plans sent to the Association by the teachers. This makes it a novel programme in this country as it provides professional supervision, continuous training, and assessment. By comparison, a similar sport programme known as Kids Athletics, also had a support package and the retraining of professionals, but the feedback and continuous monitoring was not evident as thoroughly as in the school handball project, making Handball in Schools a unique product. 


\section{Description of "Handball at School" Project}

The efficacy of handball sport education can be measured in many ways, mainly through testing the teacher's activities as well as by the quality of motor skill production of the students (Nijhar et al., 2011; Button et al., 2003) When developing our research, we were focused on students' performances besides their efficiency.

Motor skills have quantifiable measurements that can ascertain the demands and efficacy of performance. First, McMorris (2015) has suggested that skills are learned activities as opposed to being simple movements that just 'happen'. He suggested also that skills are both goal-oriented and task specific. In other words, there needs to be a definite outcome and that the movement undertaken will be purposefully conducted to meet that outcome e.g. hit a target in handball. This seems to support Juhász et al., (1980) assertion around skill: "Working without mistake, reliably." Finally, McMorris asserted that a movement requires consistency of approach, performance and conclusion to be considered skillful. Added to these variables, Schmidt \& Lee (2013) promoted the concept of complexity as being a defining agent, with complexity being dependent upon task, environment or external factors in terms of auditory or visual cues, or speed of response and/or movement. Other terms have been employed in the past such as with Fetz (cit. Rigler, 1987) in his work wrote about target and scoring accuracy in a more generally way relating not only to ballgames. He often used the concepts of scoring accuracy and repetitive precision in his work also with scoring accuracy reflecting, which means hitting a target as the result of the planned movement. He viewed this as defying moment when assessing how good the performance was. The definition of repetitive precision means that although a target may be hit once by chance, without any practice, if one can reproduce it several times after having practiced it then shows repetitive precision. Moreover, precise implementation, movement precision, movement accuracy and result accuracy concepts were defined and determined based on what Meinl termed as target focus by (Rigler, 1987). His general description identified a concept that he termed movement accuracy which meant aiming to hit the target with sports specific movements that are determined by the target. He considered practice crucial, saying that the more one practices the more one can perform different technical movements more precisely.

This has also been termed as scoring- or target accuracy by Allawy (Rigler, 1987) which means that the aim is to improve the quality of ball-passing and dribbling the ball. The "target", the surface of the target or the opponent's basket is considered as the goal or the opponents' basket, a part of their playing area, or even a team-mate who could be serve as a moving target surface when the ball is being passed to him/her. 


\section{Handball Specific Research}

The literature regarding handball has always focused more on the characteristics of physical performance in the adult age group (Wagner et al., 2014; Massuça and Fragoso, 2011).

Relative and physical fitness, resistance training, and physiological aspects have been studied with regards to professional handball players and their specific performances (Granados et al., 2007; Ortega-Becerra et al., 2018; Sporiš et al., 2019; Marques and Gonzalez-Badillo, 2006; Muratović et. al. 2015; Gürhan et al., 2016; Nikolaidis and Ingebrigtsen, 2013). Further studies focus on the sportsspecific tests regarding handball (Schwesig et al. 2016a; b). There are some research focusing on the importance of handball's tactical elements (Budi et al., 2019) and the analyzation of the games (Bilge, 2012). Meanwhile the target group in most of the researches are the elite handball players, studies focusing on school-aged children (Juhász et al., 2017) are lacking in number. In line with studies based on adult players, research with children has tend to relate to general motor skills e.g. Ingebrigsten \& Jeffreys (2012); Ingebrigsten, Rodahl \& Jeffreys, (2013); Zhunisbek et al., (2016); Broderick \& Newell (1999); Karadenizli (2016); Kayapinar et al., (2015). Only a few studies have been conducted to consider effect of handball on improving motor skills in children, albeit tenuously, as it was mainly a physical characteristics study (Ion, 2015; Juhász et al., 2016; 2017). Nonetheless, the author stated that in a special game devised for the study, the research group improved compared with a control group.

\section{Summary of Literature}

The general and working definitions above align themselves well with our proposed project as handball performance can be determined by correct technical implementation with repetitive precision, faultless activity, and with time demands. It is to these factors that our project turns to help design and assess the skill levels of primary aged school children in a variety of situations. After studying the theoretical background of skill, motor control, motor learning, movement, precision and its measurement (Bakonyi, 1969; Rigler, 1987; Buckley \& Cople, 2009; Nádori, 1989; Schmidt \& Wrisberg, 2008; Rigler \& Zsideg 1985; Müller et al., 1999; Schmidtbleicher et al., 1981; Müller, 2004; Nagy, 1978; Wulf et al., 2010; Müller, 2000) a key component of this study was to choose criteria by which skill could be evaluated. Thus, the study will assess three components of handball:

- accuracy of result - the "best" scores when aiming at a target (objective performance);

- technical form - precision of technical performance in terms of an ideal model (subjective performance);

- time on task - time taken to execute the 5 shots. 


\section{Aim of the study}

The main goal of our research was to identify whether the Handball in Schools project led to improvements in skill development, target accuracy, and speed of performance amongst primary aged school children.

\section{Research Question}

The following research question was addressed:

Are there differences in handball performances across a six-month period in three specific areas (target accuracy, technical execution, time on task) between experimental and control groups of primary school aged children who undertake daily PE?

\section{Participants}

Our study was organised using five schools from different parts of the country of Hungary. Three schools were identified for intervention with two other schools being recruited as controls. The project took place in autumn and spring, 20152016. One school (City School) was from the capital city (Budapest) while the other two were from the west and east of the country (West School and East School respectively). They joined the daily PE programme in 2015 with qualified, professional PE teachers and staff who had great experience of teaching handball. The intervention involved primary school children between the age of 8 and 10 (n $=183$ ) having 5 PE lessons in a week out of which 2 were held to acquire the basic knowledge and skills of handball. The control group $(n=110)$ consisted of school children (8 to 10-year olds) who attended two schools in the north east of the country (Rural School and North East School respectively). The children normally took 5 PE lessons a week but without handball.

Table 1. Sample by location, type of school (intervention or control), sex, ages and previous sport experience of children

\begin{tabular}{|c|c|c|c|c|c|c|c|}
\hline Group & Location & No of Part & Male & Female & Age 8 & Age 9 & Age 10 \\
\hline Intervention Group & West & 63 & 33 & 30 & 19 & 20 & 22 \\
\hline & City & 60 & 31 & 29 & 22 & 15 & 21 \\
\hline & East & 60 & 30 & 30 & 22 & 22 & 16 \\
\hline Sub Total & & 183 & 94 & 89 & 63 & 57 & 63 \\
\hline Control & Rural & 55 & 27 & 28 & 14 & 21 & 17 \\
\hline Sub Total & NE & 55 & 28 & 27 & 24 & 15 & 19 \\
\hline & & 110 & 55 & 55 & 38 & 36 & 36 \\
\hline
\end{tabular}

In terms of sampling, it was hoped to consider at least $10 \%$ of the total sample available. Out of 1430 pupils of the required ages in all five schools 293 took part in the project (20.5\%) of which the intervention groups numbered $12.8 \%$. 
Ninety-four (51.4\%) of the intervention children were boys, while 89 (48.6\%) were girls and they were allocated to groups according to age $-8,9$, and 10 years of age. In the experimental group 63 children (34.4\%) were 8 years of age, 57 children (31.1\%) 9 years of age, 63 children (34.4\%) 10 years old. The control group was composed of 38 children of 8 years of age and 36 children in each of the 9 years and 10 years of age groupings.

\section{Protocols}

In handball, movement accuracy is a very complex concept. Because of this reason, we tried to examine it via different factors so as to justify the selection of the tests undertaken. It has been conceptualized that there are three key parameters that are fundamental to handball running without the ball; motor skill performance (passing or shooting); and the ability to carry the ball (Figure 1). Factors that impact or influence those key areas and that can be measured are noted below (Factors 1-8). Due to the ages of the children and the absolute fundamental components of handball movement, it was decided to focus the study on Skill 2 - Measuring the motor skill performance - by undertaking two tests that were designed to cover three Elements (Elements 2-4).

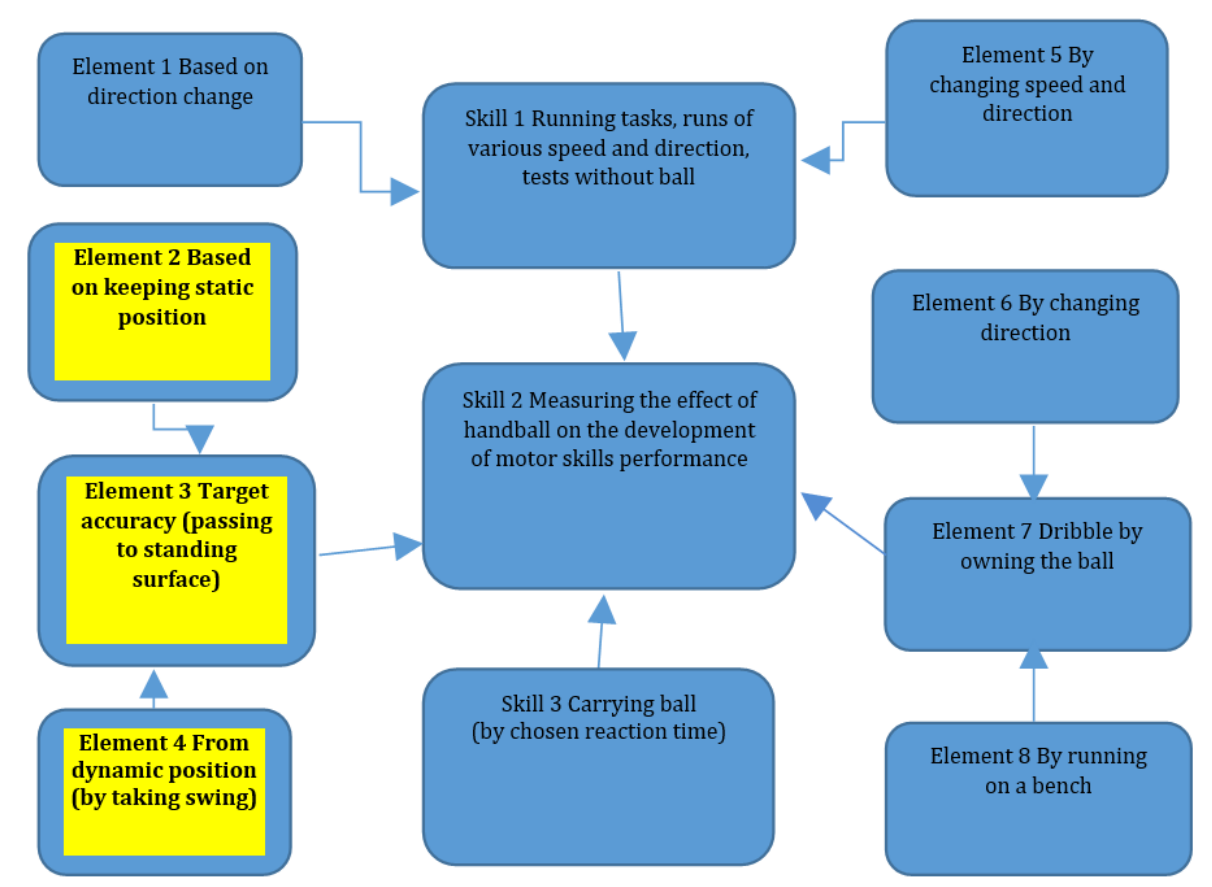

Figure 1. Structure of skills and underpinning elements in handball with measured elements of this study highlighted in bold 
In this article the results of our two tests of accuracy are described. The titles and descriptions of these tests and the methods for their evaluation are also shown below.

Originally it was planned to include 6 and 7-year-old children but during the pilot research, it became evident that those age groups had to be withdrawn as a result of an inability to perform the protocols alongside a general lack of understanding of the task. This was perceived to be indicative of their relative levels of cognitive and physical immaturity and lack of movement literacy.

\section{Test 1: Shooting in transverse straddle standing position with no run up} (to test sport specific coordination skills) (Figure 1 - Skill 2, Elements 2 and 3).

Checking target accuracy with no run up, while modelling the handball action, is not truly sport-specific as handball takes place in a dynamic environment. That is, the player (and the target, if passing to another player) moves throughout the game. However, it is an important early stage or transitional skill and thus valued by those who teach or coach handball to children. Thus, it was included as part of the project.

The students stood behind a line on the floor. Five lightweight sponge handballs suitable for the pupils' ages were placed in a small turned-up box beside the pupils' throwing hand. The task was performed using an overarm throw. Another larger box, the target box (dimension: $62 \mathrm{~cm}$ long, $42 \mathrm{~cm}$ wide, $26 \mathrm{~cm}$ tall,), was placed 5.5 meters away in the case of 8-9-year-old pupils, and 6 meters away in case of 10-year-old children. The leather covered surface of the box faced the pupil who was performing the shot. The pupil, on hearing a start whistle, had to quickly take a ball from the small box nearby and then aim at the leather covered surface of the box with the intention of hitting the leather surface with a direct hit with a ball. A direct hit was classed as accurate.

Participants were given 5 attempts to familiarize themselves with the test. Following a ten-minute rest period, each participant then undertook the trial with five attempts being recorded. Total time for the attempts was taken using a digital watch (times taken to 1/100th secs). The number of successful attempts was scored along with time taken as a measure of accuracy.

Test 2: Shooting in transverse straddle standing position with run up (to test sport specific dynamic coordination skills) (Figure 1 - Skill 2, Elements 3 and 4)

The students stood behind a line on the floor, with the distance from the line to the target surface being the same as in Test 1 (5.5-6m dependent upon age). Five sponge handballs adequate to the pupils' ages were placed behind the pupils in a small open box that was situated on the side of the pupils' throwing hand at a distance of 1.5-2m dependent upon age. The pupil, on hearing a start whistle, had to run up to the small box and, taking a ball from the box run to the line and similarly to task 1 , aim at 
the target box. The pupil had to repeat it until all 5 balls were used. The test was performed using an overarm throw.

Participants were given 5 attempts to familiarize themselves with the test. Following a ten-minute rest period, each participant then undertook the trial with five attempts being recorded. Total time for the attempts was taken using a digital watch (times taken to 1/100th secs). The number of successful attempts was scored along with time taken as a measure of accuracy.

\section{Pilot Study}

To test the materials and the protocols, a pilot study was undertaken in another Hungarian primary school. This also took place to ensure that the processes and equipment for the main study suited the age-related abilities of the participants. Specifically, the pilot study focused on the feasibility of the exercises to identify whether they were suitable for students of different ages and pre-training experience.

\section{Results and Discussion}

The data from the trials were collated and processed using SPSS.22.0 (IBM Corp, Ca, USA). The analysis grouped the population prior to calculating mean averages and standard deviations (SD). A paired-samples T-test was performed to identify differences between the two test dates (autumn and spring). Data from the control and intervention groups were compared using independent samples T-tests.

\section{Results of TEST 1: Shooting in the transverse straddle standing position with no run up (table 2)}

The experimental group was made up of those students who had 2 handball lessons out of the 5 compulsory PE lessons as part of the Handball at School programme. In terms of the first measure of accuracy that group improved compared with the control group in the six months between the autumn and spring across all three age-groups.

There were no significant changes in accuracy in the general PE control groups, albeit there was still some evidence of a trend towards better skill production. However, the experimental groups showed significant improvements in performance in each of the respective age groups (aged $8-13 \%$ improvement, $p=0.000$; aged 9 $10 \%, \mathrm{p}=0.015$; aged $10-9 \%, \mathrm{p}=0.0011$ ).

The participants were also judged on technical form as well as time on task.

Technical execution was subjectively assessed by the researchers who were looking to identify visually and record if the thrower's elbows were lifted to shoulder height or above while throwing of the attempts. It can be stated that the accuracy 
improved from autumn to spring, the elbow reaching the height of the shoulder is deemed to be a more advanced or precise ideal model of the handball shooting action. As with accuracy, the three age groups (8, 9 and 10 years) saw significant improvements from one season to the next ( $7 \%$ improvement, $p=0.03 ; 13 \%, p=0.001$; $10 \%, p=0.000$ respectively). Similar to the results for accuracy, there were no significant changes in the technical performances of the control groups.

Time on task (the overall time that it took each participant to complete their 5 throws) was viewed as a valuable assessment of skill development as handball is a dynamic activity and two age groups showed significant improvements in this measurement from autumn to spring ( 9 years - $11 \%$ improvement, $\mathrm{p}=0.01 ; 10$ years - 8\%, $\mathrm{p}=0.000$ ). Interestingly, all ages of the control groups also reported similar improvements in time taken (speed on task) which contrasts with that group's other results. This will be explored in the discussion section of the paper.

An 'eyeball' comparison of the two groups indicated that the experimental group executed the performances much faster than the control group.

Table 2. Results of Test 1 - Shooting in transverse straddle standing position with no run up (control and experimental groups)

\begin{tabular}{|c|c|c|c|c|c|c|c|c|c|c|c|c|c|c|c|}
\hline & \multicolumn{5}{|c|}{$2^{\text {nd }}$ classes, 8 years $n=63$} & \multicolumn{5}{|c|}{$3^{\text {rd }}$ classes, 9 years $n=57$} & \multicolumn{5}{|c|}{$4^{\text {th }}$ classes, 10 years $n=63$} \\
\hline & \multicolumn{2}{|c|}{ Autumn result } & \multicolumn{2}{|c|}{ Spring result } & \multirow[b]{2}{*}{$\mathrm{p}$} & \multicolumn{2}{|c|}{ Autumn result } & \multicolumn{2}{|c|}{\begin{tabular}{|l|} 
Spring result \\
\end{tabular}} & \multirow[b]{2}{*}{$\mathrm{p}$} & \multicolumn{2}{|c|}{ Autumn result } & \multicolumn{2}{|c|}{ Spring result } & \multirow[b]{2}{*}{$\mathrm{p}$} \\
\hline & mean & SD & mean & SD & & mean & SD & mean & SD & & mean & SD & mean & SD & \\
\hline \begin{tabular}{|l|} 
Accuracy Scores \\
Control Group \\
\end{tabular} & \begin{tabular}{|l|}
0.68 \\
$14 \%$ \\
\end{tabular} & 0.70 & $\begin{array}{l}0.53 \\
11 \% \\
\end{array}$ & 0.73 & 0.290 & \begin{tabular}{|l|}
0.69 \\
$14 \%$ \\
\end{tabular} & 0.75 & \begin{tabular}{|l|}
0.56 \\
$11 \%$ \\
\end{tabular} & 0.70 & 0.113 & 0.83 & $\begin{array}{l}0.81 \\
16 \% \\
\end{array}$ & 0.42 & $\begin{array}{l}0.69 \\
14 \% \\
\end{array}$ & 0.298 \\
\hline $\begin{array}{l}\text { Accuracy Scores } \\
\text { Experimental } \\
\text { Group }\end{array}$ & $\begin{array}{l}1.46 \\
29 \%\end{array}$ & 1.31 & $\begin{array}{l}2.10 \\
42 \%\end{array}$ & 1.49 & 0.000 & $\begin{array}{l}1.42 \\
28 \%\end{array}$ & 1.07 & $\begin{array}{l}1.91 \\
38 \%\end{array}$ & 1.24 & 0.015 & $\begin{array}{l}1.41 \\
28 \%\end{array}$ & 1.19 & $\begin{array}{l}1.86 \\
37 \%\end{array}$ & 1.01 & 0.011 \\
\hline $\begin{array}{l}\text { Technical Form } \\
\text { Control Group }\end{array}$ & $\begin{array}{l}0.71 \\
14 \% \\
\end{array}$ & 0.69 & $\begin{array}{l}0.58 \\
12 \% \\
\end{array}$ & 0.64 & 0.184 & $\begin{array}{l}0.53 \\
11 \% \\
\end{array}$ & 0.65 & $\begin{array}{l}0.75 \\
15 \% \\
\end{array}$ & 0.69 & 0.647 & 0.53 & $\begin{array}{l}0.70 \\
14 \% \\
\end{array}$ & 0.75 & $\begin{array}{l}0.81 \\
16 \% \\
\end{array}$ & 0.506 \\
\hline $\begin{array}{l}\text { Technical Form } \\
\text { Experimental } \\
\text { Group }\end{array}$ & $\begin{array}{l}3.08 \\
62 \%\end{array}$ & 1.77 & $\begin{array}{l}3.46 \\
69 \%\end{array}$ & 1.66 & 0.003 & $\begin{array}{l}3.39 \\
68 \%\end{array}$ & 1.99 & $\begin{array}{l}4.05 \\
81 \%\end{array}$ & 1.38 & 0.001 & $\begin{array}{l}3.52 \\
70 \%\end{array}$ & 1.80 & $\begin{array}{l}4.02 \\
80 \%\end{array}$ & 1.52 & 0.000 \\
\hline $\begin{array}{l}\text { Time on Task } \\
\text { (sec) Control } \\
\text { Group }\end{array}$ & 16.25 & 1.59 & 15.63 & 1.58 & 0.000 & 16.02 & 1.76 & 15.53 & 1.55 & 0.000 & $\begin{array}{c}14.7 \\
3\end{array}$ & 1.94 & 14.18 & 2.04 & 0.000 \\
\hline $\begin{array}{l}\text { Time on Task } \\
\text { (sec) } \\
\text { Experimental } \\
\text { Group }\end{array}$ & 11.74 & 2.06 & 11.21 & 1.80 & 0.147 & 11.49 & 2.28 & 10.23 & 2.11 & 0.001 & $\begin{array}{c}10.1 \\
9\end{array}$ & 1.82 & 9.41 & 1.71 & 0.000 \\
\hline
\end{tabular}

Note: Accuracy scores indicate how often the target was hit; Technical form scores indicate how many times the elbow was raised above shoulder level (overarm technique used appropriately); Time on Task indicates how much time was taken for the five shots of each full trial.

$\left(*\right.$ significant $\mathrm{p}<0.05^{* *}$ very significant $\mathrm{p}<0.01$, showing the change in performance in the studied group from autumn to spring)

Shooting with no run up, 2. class, 3.class, 4. class autumn and spring (score - lifted elbow - time)

\section{Results of TEST 2: Shooting in the transverse straddle standing position with run up (Table 3)}

This task is a more dynamic task than that of Test 1 and, as such, is clearly sport specific and characteristic of handball. While the previous exercise involved shooting from a standing position, this second task required for the shooting skill to be 
executed from a run up. This run-up phase ensured that there is also a 'swinging' action which made the task more difficult. There were fewer positively weighted significant differences in performances in this more complex task.

In terms of accuracy, only the youngest age group evidenced significant changes between the seasons ( 8 years of age, $15 \%$ improvement, $p=0.000$ ). There were tendicious changes in the 9 and 10 -year-old groups but they were non-significant ( $7 \%$ and $8 \%$ improvements respectively). In all cases, the accuracy scores were better in the experimental group than with the control group and the control groups made no advances in any of the ages.

Technical form did show significant improvements across all ages in the experimental group ( 8 years, $7 \%$ improvement, $\mathrm{p}=0.006$; 9 years, $5 \%, \mathrm{p}=0.000 ; 10$ years, $17 \%, \mathrm{p}=0.000$ ). All were higher than the values noted against the control group which showed no significant improvements across the two seasons, and, indeed, noted falls in performance.

Time on task showed a significant drop in the younger age group (-4\%, $\mathrm{p}=0.005$ ) but sped up in the two older age groups, but with only the oldest age group (10 years) showing significant improvements $(4 \%, p=0.00)$. Similar to the non-runup test (Test 1), the control group improved in this component, whereas they stayed the same or in most cases worsened in accuracy and technical form scores.

Table 3. The results of Test 2 - Shooting in transverse straddle standing position with run up (control and experimental groups)

\begin{tabular}{|c|c|c|c|c|c|c|c|c|c|c|c|c|c|c|c|}
\hline & \multicolumn{5}{|c|}{$2^{\text {nd }}$ classes, 8 years $n=63$} & \multicolumn{5}{|c|}{$3^{\text {rd }}$ classes, 9 years $n=57$} & \multicolumn{5}{|c|}{$4^{\text {th }}$ classes, 10 years $n=63$} \\
\hline & \multicolumn{2}{|c|}{ Autumn result } & \multicolumn{2}{|c|}{ Spring result } & \multirow[b]{2}{*}{$\mathrm{p}$} & \multicolumn{2}{|c|}{ Autumn result } & \multicolumn{2}{|c|}{ Spring result } & \multirow[b]{2}{*}{$\mathrm{p}$} & \multicolumn{2}{|c|}{ Autumn result } & \multicolumn{2}{|c|}{ Spring result } & \multirow[b]{2}{*}{$\mathrm{p}$} \\
\hline & mean & SD & mean & SD & & mean & SD & mean & SD & & mean & SD & mean & SD & \\
\hline $\begin{array}{l}\text { Accuracy } \\
\text { Scores } \\
\text { Control } \\
\text { Group }\end{array}$ & $\begin{array}{l}0.58 \\
12 \%\end{array}$ & 0.68 & $\begin{array}{l}0.58 \\
12 \%\end{array}$ & 0.64 & 0.164 & $\begin{array}{c}0.42 \\
8 \%\end{array}$ & 0.60 & $\begin{array}{c}0.42 \\
8 \%\end{array}$ & 0.69 & 0.018 & $\begin{array}{l}0.50 \\
10 \%\end{array}$ & 0.66 & $\begin{array}{c}0.47 \\
9 \%\end{array}$ & 0.74 & 0.606 \\
\hline $\begin{array}{l}\text { Accuracy } \\
\text { Scores } \\
\text { Experimental } \\
\text { Group }\end{array}$ & $\begin{array}{l}1.40 \\
28 \%\end{array}$ & 1.29 & $\begin{array}{l}2.14 \\
43 \%\end{array}$ & 1.38 & 0.000 & $\begin{array}{l}1.35 \\
27 \%\end{array}$ & 1.04 & $\begin{array}{l}1.74 \\
35 \%\end{array}$ & 1.33 & 0.078 & $\begin{array}{l}1.40 \\
28 \%\end{array}$ & 1.01 & $\begin{array}{l}1.79 \\
36 \%\end{array}$ & 1.18 & 0.449 \\
\hline $\begin{array}{l}\text { Technical } \\
\text { Form Control } \\
\text { Group }\end{array}$ & $\begin{array}{l}0.63 \\
13 \%\end{array}$ & 0.59 & $\begin{array}{c}0.59 \\
12 \%\end{array}$ & 0.69 & 0.425 & $\begin{array}{l}0.69 \\
14 \%\end{array}$ & 0.75 & $\begin{array}{l}0.64 \\
13 \%\end{array}$ & 0.76 & 0.238 & $\begin{array}{l}1.11 \\
22 \%\end{array}$ & 0.89 & $\begin{array}{l}0.69 \\
14 \%\end{array}$ & 0.79 & 0.210 \\
\hline $\begin{array}{l}\text { Technical } \\
\text { Form } \\
\text { Experimental } \\
\text { Group }\end{array}$ & $\begin{array}{l}3.19 \\
64 \%\end{array}$ & 1.86 & $\begin{array}{l}3.56 \\
71 \%\end{array}$ & 1.68 & 0.006 & $\begin{array}{l}3.40 \\
68 \%\end{array}$ & 1.96 & $\begin{array}{l}3.65 \\
73 \%\end{array}$ & 1.58 & 0.000 & $\begin{array}{l}3.25 \\
65 \%\end{array}$ & 1.97 & $\begin{array}{l}4.10 \\
82 \%\end{array}$ & 1.52 & 0.000 \\
\hline $\begin{array}{l}\text { Time on Task } \\
\text { (sec) Control } \\
\text { Group }\end{array}$ & 20.53 & 1.57 & 20.48 & 1.49 & 0.000 & 20.85 & 1.88 & 20.77 & 1.76 & 0.000 & 19.99 & 1.64 & 19.81 & 1.67 & 0.000 \\
\hline $\begin{array}{l}\text { Time on Task } \\
\text { (sec) } \\
\text { Experimental } \\
\text { Group }\end{array}$ & 19.21 & 2.23 & 20.06 & 2.54 & 0.005 & 18.28 & 2.87 & 16.90 & 2.27 & 0.127 & 16.50 & 2.55 & 15.90 & 2.28 & 0.000 \\
\hline
\end{tabular}

${ }^{*}$ significant $\mathrm{p}<0.05^{* *}$ very significant $\mathrm{p}<0.01$, showing the change in performance in the studied group from autumn to spring)

Shooting with run up, 2. class, 3.class, 4. class autumn and spring (score - lifted elbow - time)

From table $5\left({ }^{*}\right.$ significant $\mathrm{p}<0.05^{* *}$ very significant $\mathrm{p}<0.01$, showing the change in performance in the studied group from autumn to spring) 


\section{Summary}

The research question asked whether there would be differences in handball performances across a six-month period in three specific areas (target accuracy, technical form, time on task) between experimental and control groups of primary school aged children who undertake daily PE?

In Test 1, the shooting with no run up assessment, the summation of the responses indicates that across the three components of skill that were tested, the three age groups in the experimental group significantly improved compared with control groups. The only measure in which there was no significant improvement was on time on task in the 8-year olds. The control groups showed no significant improvements or dropped performance in all accuracy and technical form tests across the three age groups. However, it has to be noted that those children in the control groups all increased the speed of executing their tasks with significant improvements in all age groups.

In Test 2 in which the children do a run up before shooting, the results were a bit mixed. There were significant improvements in the technical form scores across all age groups. However, in terms of accuracy and time on task scores, only the youngest children showed significant differences in both measures. The 10-year-old participants showed significant improvements on time on task. All other scores showed that the experimental group improved but not significantly.

Similar to Test 1, the control group showed significant improvements in time on task but either 'stood still' or performed less well in the accuracy or technical form values.

\section{Conclusion}

During this project primary school aged children were tested with handballspecific movements. At this age and stage of children's development, the skills and movements being tested were complex and included relatively static tests as well as more complex holistic assessments of movement.

There were a number of key problems that can be identified from the results. First, the results showed that the Handball at School project, involving 2 sport-specific lessons in a week, helped to improve speed coordination abilities and shooting accuracy of all the children in the experimental group. In Test 1 in which the children did not run-up but executed the skills from a standing position, all three age groups in the experimental section showed significant improvements in both accuracy and in technical form exhibited. The older two age groups also showed significant differences in the speed at which they undertook the task. In Test 2 in which the run up was added prior to the execution of the skills, the results were slightly more varied. Technical form showed significant improvements across the age groups within the 
experimental grouping, while the time on task data identified significant improvements in both the younger children and the 10-year olds.

However, in the control group, the time on task was the only variable tested that showed significant improvements across the three age groups. All other changes were mainly non-significant. Thus, there is no doubt that the intervention worked and handball specific input led to better performances.

That information is of use to this national sports federation as well as others who wish to develop their sports further: simple projects with adequate teacher training and supported by sufficient age-related resources leads to impactful change. The challenge for the future is to track this project as the children mature and identify if the early age results continue into adolescence and beyond.

In terms of the benefits of daily physical education per se, further work is required. This project was designed to consider Handball at School within the setting of daily physical education. The results very favourably noted that handball skills improved in most areas in the experimental group BUT it also identified performance decrements in many of the areas in the control group.

In Test 1 (with no run up), both accuracy and technical form dropped over the six months period, except in the older age group in which form improved. Only in the time on task did the control group improve significantly or show a trend towards improvement in Test 1. Likewise, in Test 2 (with a run up), there were no improvements at all and the trends indicated that at best the scores were the same but mostly worsened. The exception again was in the time on task in which all three age groups showed quicker responses.

While the result is perhaps surprising as this latter group still undertook daily physical education and it might have been assumed that skills would have improved, not from the sports specific training (that this group did not receive) but from general movement skills that the children should have gained, it is suggested that the increase in speed on time on task is a mitigating factor. It is well recognized that the more complex a task, then adding speed to it complicated it further. The authors feel that this might have impacted on the study as it was one of the key instructions: the children were bing timed on the shooting tasks and new that they were being assed not only on accuracy and technical form but on speed. If the children focus on the 'easiest' component of their skills repertoires at their ages, speed of action or doing things faster, this is likely to have cause an overload in the areas that are dealing with accuracy and execution with a focus being elsewhere. The only way to test this would be for the control group to now undertake the test without the speed component as well as with the speed component and look for any differences. A suitable hypothesis could be that daily physical education would positively assist young people to develop 
handball skills despite not taking part in regular handball so long as they were allowed to develop at their own pace. The fact that the experimental group showed improvements in accuracy and technical form, even when speeding up tends to support the premise.

Aside from the above suggestion for additional work, future studies should include children who do not have the benefit of daily physical education to identify what differences there are between those who have that opportunity, and those who do not. Such an addition could help to cement the overall importance of daily physical education in the life of a child.

\section{Acknowledgement}

The creation of the publication was supported by the project "GINOP-2.3.2-152016-00062 Improving the quality of life in Eastern Hungary: Nutrition and performance biology and biotechnology experimental research and technological development for the prevention and treatment of human diseases" project.

\section{References}

András, K. (2014). The sporting economy increment of the TAO subsidy scheme. In: The role of academic education in sport, in professional sport and in the Olympic movement, with special regard to the situation of sports tax-supported sports (TAO) and the utilization of grants Conference Tanulmánykötete. Date of the conference: 2013, nov 7-8, University of Debrecen, Editor (Petridis Leonidas). Debrecen, 2014, 12-22 p. (In Hungarian).

Bács, Z. \& Bácsné, Bába É. (2014). Impact and organizational management of the TAO support system in Debrecen. In: The role of academic education in sport, in professional sport and in the Olympic movement, with special regard to the situation of sports tax-supported sports (TAO) and the utilization of grants Conference Tanulmánykötete. Date of the conference: 2013, nov 7-8, University of Debrecen, Editor (Petridis Leonidas). Debrecen, 2014, 22-36 p. (In Hungarian).

Baidog, A., \& Herman, G.V. (2018). The Influence of Sports and Physical Activity on the Metabolic Syndrome: A Systematic Review. Analele Universităţii din Oradea. Fascicula Educaţie Fizică şi Sport, 28(1), 39-45.

Bakonyi, F. (1969). Influence of quantity and quality of physical education on the demand for sports. A testnevelés tanítása. Budapest, Mưvelódésügyi minisztérium módszertani folyóirata 5, 3, 75-78 (In Hungarian).

Bardóczy, G. (2014). The situation and perspectives of spectator-team sports support. The role of academic education in sport, in professional sport and in the Olympic movement, with special regard to the situation of sports tax-supported sports (TAO) and the utilization of grants Conference Tanulmánykötete. Date of the conference: 2013, nov 7-8, University of Debrecen, Editor (Petridis Leonidas). Debrecen, 2014, 50-72 p. (In Hungarian).

Bilge, M. (2012). Game analysis of Olympic, World and European Championships in men's Handball. Journal of Human Kinetics, 35(1), 109-118.

Börnhorst, C., Tilling, K., Russo, P., Kourides, Y., Michels, N., Molnár, D., \& Ahrens, W. (2016). Associations between early body mass index trajectories and later metabolic risk factors in European children: the IDEFICS study. European journal of epidemiology, 31(5), 513-525.

Broderick, M. P., \& Newell, K. M. (1999). Coordination patterns in ball bouncing as a function of skill. Journal of motor behavior, 31(2), 165-188.

Buckley, R., \& Caple, J. (2009). The theory and practice of training. Kogan Page Publishers.

Budi, D. R., Hidayat, R., \& Febriani, A. R. (2019). The Application of Tactical Approaches in Learning Handballs. JUARA: Jurnal Olahraga, 4(2), 131-139. 
Button, C., Macleod, M., Sanders, R., \& Coleman, S. (2003). Examining movement variability in the basketball freethrow action at different skill levels. Research quarterly for exercise and sport, 74(3), 257-269.

Cole, T. J. (2004). Children grow and horses race: is the adiposity rebound a critical period for later obesity? BMC pediatrics, 4(1), 6.

Dajnoki, K., Becsky A., Szabados Gy. (2015). Sportorganisation HR (In Hungarian).

EU Physical Activity Guidelines (2008). Recommendations for policy measures to promote healthpromoting physical activity Fourth consolidated text. Jóváhagyta az Approved by the EU "Sport and Health" working party, September, p. 44 (In Hungarian).

Granados, C., Izquierdo, M., Ibanez, J., Bonnabau, H., \& Gorostiaga, E. M. (2007). Differences in physical fitness and throwing velocity among elite and amateur female handball players. International Journal of Sports Medicine, 28(10), 860-867.

Gürhan, S., Malik, B., Kürsat, H. (2016). Comparison Of Aerobic, Anaerobic Power Features Basketball And Handball Team Players, IN: Niğde University Journal Of Physical Education And Sport Sciences, 10 (3).

Ingebrigsten, J., Jeffreys, I. (2012). The relationship between speed, strength and jumping abilities in elite junior handball players. Serb J Sports Sci., 6, 83-88.

Ingebrisgten, J., Rodahl, S., Jeffreys, I. (2013). Physical Characterstics and Abilities of Junior Elite Male and Female Handball Players. J Strength Cond Res., 27, 302-309.

Ion, M. (2015). Training Modeling Children Beginners in Practice Handball Game. Procedia-Social and Behavioral Sciences, 180, 1269-1275.

Juhász, I., Boda, E., Bíró, M., Müller, A., Macra-Oşorhean, M.D. (2016). Impact of teaching handball on the improvement of target accuracy of students in consideration for the impact assessment of the project "Handball at school". Studia Universitatis Babes-Bolyai Educatio Artis Gymnasticae 61(4), 15-27.

Juhász, I., Marczinka, Z., Ökrös, Cs., Papp, Gy., Varga, J., Zsiga, Gy., Marczinka, Z. (ed.), (2017). Age group training book: age 6-18 [s. l.] - Magyarország, Magyarország: Kék Európa Stúdió, 219 p. (In Hungarian).

Juhász, I., Müller, A., Boda, E., Biró, M. (2017). Introduction of the „Handball at School” project and the examination of the impact on the motoric performance on school children. Magyar Edzö: Módszertani És Továbbképző Folyóirat, 19(2), 52-56 (In Hungarian).

Juhász, J., Szőke, I. O., Nagy, G., Kovalszky, M. (1980). Hungarian Interpretive Handbook. Akadémiai Kiadó. 1115-1992 (In Hungarian).

Karadenizli, Z. I. (2016). The Effects of Plyometric Education Trainings on Balance and Some Psychomotor Characteristics of School Handball Team. Universal Journal of Educational Research, 4(10), 2292-2299.

Kayapinar, F. C., Aydemir, R., \& Aydemir, D. H. (2015). The Effect of Training Program on Physical Characteristics and Social Development of Boys. Academic Journal of Interdisciplinary Studies, 4(1 S2), 139.

Magyar Közlöny (2016). 126. issue 5. attachment 22/2016 (VIII.25) EMMI order (In Hungarian).

Marques, M. A. C., \& González-Badillo, J. J. (2006). In-season resistance training and detraining in professional team handball players. Journal of strength and conditioning research, 20(3), 563.

Martos, É., Kovács, V. A., Bakacs, M., Kaposvári, Cs., Lugasi A. (2012). National Nutrition and Nutrition Status Test-OTÁP 2009. Orvosi Hetilap. 153. évf., 26. sz. pp. 1023-1030.

Massuça, L., Fragoso, I. (2011). Study of Portuguese handball players of different playing status. A morphologicaland biosocial perspective. Biology of Sport ,28 (1), 37.

McMorris, T. (2015). Exercise-Cognition Interaction: Neuroscience Perspectives. Champaign: Ill. Human Kinetics.

Müller, A. (2000). Accuracy of Throws as a Result of Non-Specific Training, The 14th International Congress on Sport Sciences for Students - 2000 (Nemzetközi Tudományos Diákköri Konferencia, Phd szekció), Bp. április 13-14 (In Hungarian).

Müller, A., Rigler, E., Derzsy, B. (1999). Development of kicking accuracy as a result of non-specific training. III. Országos Sporttudományos Kongresszus kiadványkötetében, Mónus A. (Ed.), Kiadó: Magyar Sporttudományi Társaság, 74-77. p (In Hungarian).

Muratović, A., Petković, J., Bojanić, D., \& Vasiljević, I. (2015). Comparative Analysis of Motor and Specific Motor Abilities Between Handball Players and Non-Athletes in the Cadet Age from Montenegro. Acta Kinesiologica, 1, 70-74.

Nádori, L. (1989). Features of fast and accurate movement. A Testnevelési Főiskola Közleményei. 1.sz. 45-49 p. (In Hungarian).

Nagy, Gy. (1978). Psychology in practice. Action Learning Motion Transfer. Akadémiai Kiadó. 9-68 p. (In Hungarian). 
NAT (2012). New Pedadodical Reivew 1- 3, 30 -256 (In Hungarian).

Nijhar, J., Bianchi-Berthouze, N., \& Boguslawski, G. (2011, May). Does movement recognition precision affect the player experience in exertion games?. In International Conference on Intelligent Technologies for interactive entertainment (pp. 73-82). Springer, Berlin, Heidelberg.

Nikolaidis, P. T., \& Ingebrigtsen, J. (2013). Physical and physiological characteristics of elite male handball players from teams with a different ranking. Journal of human kinetics, 38, 115-124.

Ortega-Becerra, M., Pareja-Blanco, F., Jiménez-Reyes, P., Cuadrado-Peñafiel, V., \& González-Badillo, J. J. (2018). Determinant factors of physical performance and specific throwing in handball players of different ages. The Journal of Strength \& Conditioning Research, 32(6), 1778-1786.

Papp, B.M., Șerbescu, C., Caciora, T., Baidog, A., Varodi, M.O. (2019). The Effects of a Physical Activity Program on Body Composition and Physical Condition in the Overweight Adult. Analele Universităţii din Oradea. Fascicula Educaţie Fizică şi Sport, 29(1), 1-9.

Rigler, E. (1987). Reproducibility and performance constancy of human motion. (Excerpt from the author's thesis) A Testnevelési Főiskola közleményei. 1. sz. Melléklet. 3-96 p. (In Hungarian).

Rigler, E., \& Zsidegh, M. (1985). Examining the accuracy of motion reproduction. A testnevelési Főiskola Közleményei. 1. sz. 129-151 p. (In Hungarian).

Schmidt, R. A. \& Lee, T. (2013). Motor Learning and Performance $5^{\text {th }}$ Edition: From Principles to Application. Champaign: Ill: Human Kinetics.

Schmidt, R. A. (1996). Motion control and motion learning. MTE. Bp. 303-311 (In Hungarian).

Schmidt, R. A., Wrisberg, C. A. (2008). Motor learning and performance: A situation-based learning approach. Human kinetics.

Schmidtbleicher, D., Rigler, E., Müller, K. J. (1981). Examination of motion accuracy in the example of "recline". Testnevelési Föiskola Közleményei, 3, 129-143 p.

Schwesig, R, Hermassi, S, Hoffmeyer, B, Irlenbusch, L, Fieseler, G, Noack, F, Delank, Ks, Gabbett, Tj, Chelly, M. S. (2016). Relationship between the handball-specific complex-test and intermittent field test performance in elite professional handball players. In: The Journal of sports medicine and physical fitness · December 2016.

Schwesig, R., Koke, A., Fischer, D., Fieseler, G., Jungermann, P., Delank, K. S., \& Hermassi, S. (2016). Validity and reliability of the new handball-specific complex test. The Journal of Strength \& Conditioning Research, 30(2), 476-486.

Sporiš, G., Vuleta, D., Vuleta Jr, D., \& Milanović, D. (2010). Fitness profiling in handball: physical and physiological characteristics of elite players. Collegium antropologicum, 34(3), 1009-1014.

Tătar, C.F., Herman, G. V., \& Pețan, P. (2018). Sport and physical activity engagement in Romania. Geosport for Society, 8(1): 40-50.

Wagner, H., Finkenzeller, T., Würth, S., \& Von Duvillard, S. P. (2014). Individual and team performance in team-handball: A review. Journal of sports science \& medicine, 13(4), 808.

Wulf, G., Shea, C., Lewthwaite, R. (2010). Motor skill learning and performance: a review of influential factors. Medical education, 44(1), 75-84.

Zhunisbek, D., Kudasheva, L., Kefer, N., \& Akhmetkarim, M. (2016). Methodological features physical preparation of students handball players. International Journal of Environmental and Science Education, 11(18), 12183-12196.

Web-sites sources:

Eurobarometer [2010]. Sport and Phisical Activity. Retrieved: 2018. december 12. from: http://ec.europa.eu/public_opinion/archives/ebs/ebs_334_fact_hu_en.pdf

Müller, A. (2004). Motion tests on motion smoothness and power constant. (Dissertation) Nevelés- és Sporttudományok. 2004. Semmelweis Egyetem Testnevelési és Sporttudományi Kar Doktori Iskolája, Bp. $\quad$ Retrieved $2018 . \quad$ november 02. from: http://phd.semmelweis.hu/mwp/phd_live/vedes/export/mulleranetta-d.pdf (In Hungarian).

Sport XXI. Nemzeti Sportstratégia 2007-2020. Retrieved 2019. june 21. From: https://mkogy.jogtar.hu/?page=show\&docid=a07h0065.0GY (In Hungarian)

The role of the National Core Curriculum in content regulation. Retrieved: 2004. december 20. from: http://www.om.hu/letolt/kozokt/nat2003/kr/02_bevezetojavveg.rtf. 